VOL. 01 NO. 01, JUNE 2019

\title{
HOW TO TEACH LISTENING IN SENIOR HIGH SCHOOL
}

\author{
Bradhiansyah Tri S. \\ Universitas Nurul Jadid \\ bradhiansyahs@gmail.com
}

\begin{abstract}
Many teachers considered that listening is the most important skill of any other language skills(Aziez \& Alwasilah, 1996). Moreover, the discussion of an issue about the use of authentic listening material is just fierce in listening as it is in reading(Harmer, 2001). However, the teacher should have to look for the simplest method of teaching listening to overcome its difficulties; to teach it effectively; and to achieve the goals of teaching listening successfully, such as teaching students to acquire vocabularies, grammatical understanding, and good pronunciation.

The Purposes of the study are to overcome the difficulties in teaching listening; to improve teacher's creativity in teaching listening; and to provide the teacher with some alternative methods of teaching listening.

Based on the study it can be concluded that, first, the effective listening will produce successful listening. Second, the reason of using listening in the classroom is to let the students to hear different varieties and accent of English instead of the voices of their teacher which may be full of idiosyncrasies. Third, the listening materials are geared with the students' needs, levels, and interests. Fourth, there six principles for listening; Encourage students to listen as often and as much as possible, help students prepare to listen, once may not be enough, encourage students to respond to the content of a listening, not just to the language, different listening stages demand different listening tasks, and good teachers exploit listening texts to the full.
\end{abstract}

keywords: Teaching Listening, Senior High School, Effectively

\section{INTRODUCTION}

\section{A. The Background of Teaching Listening}

Many teachers considered that listening is the most important skill of any other language skills(Aziez \& Alwasilah, 1996). Moreover, the discussion of an issue about the use of authentic listening material is just fierce in listening as it is in reading(Harmer, 2001). However, the teacher should have to look for the simplest method of teaching listening to overcome its difficulties; to teach it effectively; and to achieve the goals of teaching listening successfully, such as teaching students to acquire vocabularies, grammatical understanding, and good pronunciation.

Through this paper, the teacher will comprehend the effective listening, and then the students will not be worried of having listening test, and finally they will be more confident than before.

\section{B. The Purposes of Teaching Listening}

There are two major reasons for teaching listening(Harmer, 2008), namely:

1. To let the students hear varieties and accent rather than just the sound produced through the mouth by their teacher with its own idiosyncrasies.

2. It helps students to gain their ability or behavior of language subconsciously even if teachers do not draw attention to its special feature.

\section{REVIEW OF RELATED LITERATURES}

\section{A. Definition of Listening}

Listening is meant literally as giving attention so as to hearing (what someone is saying)(Kernerman, 1996). This comes through knowing how the words sound; what they mean; how they are put together in sentences and expressions; and how to predict the purpose and content of message from other clues, such as tone of voice, facial expression, gestures, and other body language.

According to Barthes, 1985 listening is the interpretative action taken by someone in order to understand and potentially make meaning of something they hear. In other words, listening activity has at least 


\section{VOL. 01 NO. 01, JUNE 2019}

three main goals, namely the students have fluent pronunciation as spoken by native speaker in the audio recording; they have good grammatical understanding; and eventually they have many vocabularies. Listening refers to a complex cognitive process that allows a person to understand spoken language (Rost, 2005).

From those three definitions, it can be concluded that listening is the ability to decode and encode aimed for reproducing accurately, reefing student's comprehension of grammar, and developing their own vocabularies.

In addition, listening comprehension requires listeners to interpret all messages they hear and see. Indeed, to know or realize the meaning of words or messages, the listener to use both their knowledge of vocabulary and grammar and their background knowledge of typical messages and situations.

In other words, effective listening means being able to understand the language (grammatical ability) and the way the language is used in different situations (interactional ability).

Of course, effective listening will produce successful listening. The teacher should know that successful listening is affected by many factors: some external and some internal (Flood, Lapp, Squire, \& Jensen, 2003). External factors may include clarity of the speaker, dialect of the speaker, content of the material, mode of transmission (person, audio recording recorder, stereo), speed of transmission, and environmental noise. While internal factors that affect listening comprehension may include mental and physical health of the listener, intelligence of the listener, attention to the task, previous experience, and listener's attitude.

\section{B. Teaching Listening in General}

Before teaching listening, the teacher should consider firstly the needs of students, their interests, and of course, their level, and after that the teacher should have determine the technique of listening that is used.

Generally, teaching listening depends on the student's level and the kind of tasks that go with anaudio recording. There may well be some authentic material that is usable by beginners such as pre-recorded announcements, telephone message, etc. More difficult material may be appropriate for elementary students provided the questions they are asked do not demand detailed understanding. Advanced students may benefit from scripted material provided that it is interesting and subtle enough - and provided the tasks that go with it are appropriate for their levels.

Here is the table of different kinds of listening based on the different level of students with the technique of teaching listening(Harmer, 2008).

Table 1

Kinds of Listening

\begin{tabular}{|c|c|c|c|c|c|}
\hline \multirow[t]{2}{*}{ NO } & \multirow{2}{*}{$\begin{array}{c}\text { KIND OF } \\
\text { LISTENING }\end{array}$} & \multicolumn{3}{|c|}{$\begin{array}{l}\text { STUDENT'S } \\
\text { LEVEL }\end{array}$} & \multirow[t]{2}{*}{ TECHNIQUE OF LISTENING } \\
\hline & & ELM & INT & $\mathrm{ADV}$ & \\
\hline 1 & $\begin{array}{l}\text { Informational } \\
\text { listening }\end{array}$ & & $\mathrm{X}$ & $\mathrm{X}$ & $\begin{array}{l}\text { In } 3 \text { groups, students listen to three different audio recordings } \\
\text { (witness reports, phone conversations, arranging meeting, etc.) } \\
\text { by comparing notes, they have to works out the truth (jigsaw } \\
\text { listening). }\end{array}$ \\
\hline 2 & $\begin{array}{l}\text { Interpersonal } \\
\text { listening }\end{array}$ & $\mathrm{X}$ & & & $\begin{array}{l}\text { Students listen to a phone message being given. They have to } \\
\text { record the message on a message pad. }\end{array}$ \\
\hline 3 & $\begin{array}{l}\text { Informational } \\
\text { listening }\end{array}$ & $\mathrm{X}$ & & & $\begin{array}{l}\text { Students hear the sound effects. They use them to construct a } \\
\text { story of what actually happened. }\end{array}$ \\
\hline 4 & $\begin{array}{l}\text { Informational } \\
\text { listening }\end{array}$ & & $\mathrm{X}$ & & $\begin{array}{l}\text { Students listen to a narrative and have to plot the characters' } \\
\text { movement on a map. }\end{array}$ \\
\hline 5 & $\begin{array}{l}\text { Informational } \\
\text { listening }\end{array}$ & & & $\mathrm{X}$ & $\begin{array}{l}\text { Students listen to news broadcast and compare it with a } \\
\text { newspaper report. What are the differences? }\end{array}$ \\
\hline 6 & $\begin{array}{l}\text { Informational } \\
\text { listening }\end{array}$ & & $\mathrm{X}$ & & $\begin{array}{l}\text { Students listen to three poems being read by three different } \\
\text { people. They have to choose a mood/color for each and say } \\
\text { which they like best. }\end{array}$ \\
\hline 7 & $\begin{array}{l}\text { Interpersonal } \\
\text { listening }\end{array}$ & & $\mathrm{X}$ & & $\begin{array}{l}\text { Students listen people describing their occupations. They have } \\
\text { to decide what people look like and what the occupations are. }\end{array}$ \\
\hline 8 & $\begin{array}{l}\text { Interpersonal } \\
\text { listening }\end{array}$ & $\mathrm{X}$ & & & $\begin{array}{l}\text { Students listen to a story. They have to put some pictures in the } \\
\text { correct order to match the story. }\end{array}$ \\
\hline 9 & $\begin{array}{l}\text { Interpersonal } \\
\text { listening }\end{array}$ & & $\mathrm{X}$ & & $\begin{array}{l}\text { Students listen to a recorded message of films, times, prices, } \\
\text { etc., and decide which film they are going to see when. }\end{array}$ \\
\hline
\end{tabular}

Note:

- ELM: Elementary

INT: Intermediate

ADV: Advanced 


\section{VOL. 01 NO. 01, JUNE 2019}

- Informational listening is listening activity of giving information in one-way communication

- Interpersonal listening is listening activity of giving information in two-way communication.

After deciding the student levels, the teacher should have to prepare the authentic listening material carefully. If, for instance, an audio recording of a political speech is played for elementary students, they will not understand a word. It could be argued that such an audio recording would at least give them a feel for the sound of the language, but beyond that it is difficult to see what they would get out of it. If, on the other hand, a realistic (though not authentic) audio recording of telephone conversation is given, they may learn much about the language - and start to gain confidence as a result.

Again, the teacher should know that listening demands listener engagement, too. Long audio recording on subjects which students are not interested in at all will not only be de-motivating, but students might "switch off' (confused), and once they do that it becomes difficult for them to tune back into the audio recording. Finally, their comprehension is lost and the listening becomes valueless.

\section{The Advantages of Teaching Listening to the Students}

There are many specialties in which listening activities differ from other classroom exercises (Harmer, 2008)firstly; audio recordings go at the same the rate at which it was played for every student. Unlike language study or speaking practice or even reading, where individual students can read (to some extent) at their own place, listeners to an audio recording cannot flick back to a previous paragraph; re-read headline, stop to look at the picture and think for a while before continuing. On the different side, they have to go with the speed the voice(s) they are listening to. Of course, they can stop audio recording and rewind them, but essentially, the speed of the speaker(s) dominates the interaction and sensitivity to comprehend the language context and encourage them to respond to the content of listening.

It is perhaps this relentlessness of audio recording, which accounts for the feeling of panic, which many students have a particular situation affect them or happen to them during listening activities. If they fail to recognize a word or phrase they haven't understood, and if, therefore, they stop to think about it, they often miss the text part of the audio recording and are soon falling behind in term of comprehension. It is especially for this reason that students have to be encouraged to listen for general understanding first rather than trying to pick out details immediately. They must get into as a thing that they do often of letting the whole audio recording "wash over tem" on first hearing, thus achieving general comprehension before returning to listen for specific detail. Through this drill, the students will be accustomed to understand a spoken text and recognize a word or phrase, or even a complete sentence in a very short time.

Listening is special too because language which was expressed in speech, especially when it is informal, has a number of unique features including the use of incomplete utterances (e.g. "Dinner?"), repetition (e.g. "I'm absolutely sure, absolutely sure you know that she is right"), hesitations (e.g. "Yes, well, mm, yes, possibly, but, err, ....") etc. Experience of informal spoken English together with appreciation of other spoken factors, the tone of the voice, the intonation the speakers use, rhythm, and background noise, will help students to tease meaning out of such speech phenomena. Of course, this exercise will also rehearse the students' strategic competence.

Because of its special characteristics, teachers need to ensure that students are well prepared for listening and that they are clearly able to hear what they listen to. These and other concerns are summarized in the following six principles.

\section{The Principles behind the Teachingof Listening}

Thereare six main principles for the teacher to note during listening activity(Harmer, 2008). Those are as follow:

○ Principle 1: Encourage students to listen as often and as much as possible.

- Principle 2: Help students prepare to listen.

○ Principle 3: Once may not be enough.

- Principle 4: Encourage students to respond to the content of a listening, not just to the language.

○ Principle 5: Different listening stages demand different listening tasks.

○ Principle 6: Good teachers exploitlistening texts to the full.

\section{E. Teaching Listening in Senior High School}

Hence, teaching listening for senior high school students should meet with their interests such as:

$\checkmark$ The authentic materials (audio recording) must consist of the text which is narrative, procedural, spoof, recount, report, news items, descriptive, anecdote, analytical exposition, hortatory exposition, discussion, commentary, and review.

$\checkmark$ The listening can be either informational or interpersonal listening.

$\checkmark$ The teacher should have to classify the students' levels, whether they are elementary students, 


\section{VOL. 01 NO. 01, JUNE 2019}

intermediate students, or advanced students in order to meet with their needs and interests.

Eventually, it is recommended for the teacher to use the supplementary handbook and other materials. The audio recording should contain various techniques of teaching listening that assesses students' listening ability in many aspects, such as listening to song, poem, news, dialogue, dictation, cloze listening, guessing, and so on. Moreover, the supplementary listening material, such as students' worksheet, is based on the themes and the topics in the students' handbook.

\section{THE PROPOSED TECHNIQUE FOR TEACHING LISTENING IN SENIOR HIGH SCHOOL}

\section{A. Communicative Teaching of Listening}

There is no debate about the merit of listening to audio recordings as an activity that strengthens listening capacity (Flood et al., 2003). Listening capacity is the main goal of teaching listening as explained in the previous discussion, that is the ability of students to comprehend oral text as well as they can understand written text in reading activity.

Listening itself requires long silent period to do, meaning, it is a kind of passive activity. The teacher can improve listening to be an active activity with communicative teaching listening (Aziez \& Alwasilah, 1996). Communicative listening is a kind of listening that involves students to comprehend and react what is being spoken, and the teacher does not let them just hear and listen, but ask them some questions in whilst activity. This activity is described and arranged in seven stages as follows:

Stage 1 : The teacher motivates students by discussing their experiences in real life related to the topic of listening script.

Stage 2 : The teacher explains the goals of teaching learning activity and the topic which will be listened to.

Stage 3 : The teacher plays the audio recording for twice or three times. And the students fill the blanks of the conversation or dialogue.

Stage 4 : The teacher asks them some simple questions. For example: "How many speakers can you hear?"

Stage 5 : The teacher plays the audio recording once more, and then asks "How many times can you hear these words?" (Tick the column). The teacher spread out the table of words to the students firstly, or if they have had the listening worksheet, then the teacher should have to ensure the students know how to do with the task.

Stage 6 : The teacher plays the recording once more, and thenasks "Listen again and circle the words you hear."

Stage 7 : The teacher plays the recording once more, and then asks "How many questions can you hear?" (Tick the appropriate box).

The listening activity above is rich in communication. The teacher always asks the students again and again with some tasks and the students react immediately to what the teacher instructed, and finally they are able to comprehend the oral text totally, and as a result their comprehension is full and the listening is also useful. In other words, the teacher teaches listening effectively. As told before that effective listening is being able to understand the language (grammatical ability) and the way the language is used in different situations (interactional ability). In addition, effective listening will guarantee the success of listening activity.

There are three kinds of communicative listening (Harmer, 2001). Those are:

\section{Filling in forms}

The simplest kind of listening materials of this kind involves filling in forms of one kind or another. When the teacher and students have checked that they have filled in the forms correctly they can organize a follow-up task in which students interview each other to fill in similar personal details. To make it more fun the teacher can prepare a series of role cards so that students are not repeating information about themselves which they have already used in smaller chunks for language practice.

2. Directions

Understanding directions is clearly a vital skill and in this activity, the elementary-level students have to listen to the audio recording in order to find a spot on a map. As a result, this activity drills students to bevery careful and attentive to the text mentioned.

\section{Jigsaw listening}

Jigsaw listening is a listening drill to describe an activity in which different students get different information from different listening passages which they then have to share in order to perform some kinds of task.

For instance, three students may each listen to an audio recording conversation. The conversation they listen to is different in each case (each person listens to only one conversation) thus giving each student a different piece of the "jigsaw". The students, then join together to, use their piece to put the jigsaw together. In many ways the idea is similar to the story construction activities except that here the original input comes 
VOL. 01 NO. 01, JUNE 2019

from listening material, not pictures or written exercises.

Thus, inthose listening activities explained above, the teacher should encourage the students to communicate and collaborate with others actively. Again, this will be successful if the students are well prepared and the teacher instructs them to discuss and solve the problems collaboratively.

\section{B. Dictogloss}

Another technique of teaching listening communicatively is dictogloss(Aziez \& Alwasilah, 1996). In this technique, the teacher reads a simple text for the students with normal speed and they are asked to write as many as they can. After that, they work in small group to reconstruct some words they wrote. This technique is like a technique of traditional dictation, even though, it is a kind of superficial technique of teaching.

Dictation is an excellent way to reinforce listening and writing skills (Flood et al., 2003). The task demands of dictation exercises are well-focused and important for the student's education. During dictation, the students have an opportunity to practice all the following skills:

1. Listening attentively

2. Listening with concentration

3. Handwriting

4. Punctuation

5. Spelling

There are four stages in this technique are:

Stage 1 : Pre-Dictation

The teacher motivates the students by questioning and discussing the stimulus picture, explaining some difficult vocabularies, ensuring that students really understand what to do, making sure that they are in the right group.

Stage 2 : Whilst-Dictation

The students listen to the dictation twice. Firstly, they just listen and obtain the general comprehension about the text. Secondly, they write only the context of the text to help them for reconstruction. It is better if the students listen to the dictation from the audio recording (not from the teacher his self) on behalf of listening consistency.

Stage 3 : Post-Dictation (Reconstruction)

At the end, the students collect their notes and re-write the text with their own sentences. During this activity, the teacher is not allowed to correct their text or provide some difficult glossaries.

Stage 4 : Evaluation (Analysis and Correction)

The students compare their works the original text written on the board on LCD Projector sentence per sentence, and after that they should analyze and correct their mistakes, and finally the teacher should assess their works.

\section{Listening Games}

There are many kinds of listening games that teacher may apply them for the students, such as:

1. Simon says

2. Telephoning

3. Clock faces

4. Marking illustration

5. Guess the title of the poem

6. Name and product

7. Listening to a song

In this activity, the teacher should be creative and innovative, and then the listening activity will be a jolly game for the students. Here some example of developing and managing the teaching of listening game.

1. Simon Says

This is the most famous listening game of any other games. The teacher asks the students some instructions, and they will obey the orders, if he begins with a word "Simon says ...."

Materials : Stationary

Directions : Say the following - Listen carefully! I will order you to do something, and you just obey my instructions if I begin my words with "Simon says ...." Now, work in a small group. One group contains ten students. Every group will compete another group. The winner is the group which do fewest mistake or the group which responds the order quickly and rightly.

Game Roles :

\begin{tabular}{|l|l|}
\hline \multicolumn{1}{|c|}{ THE TEACHER } & \multicolumn{1}{c|}{ THE STUDENTS } \\
\hline Stand up ...! & (No respond) \\
\hline Simon says, "Stand Up!" & They stand \\
\hline
\end{tabular}


VOL. 01 NO. 01, JUNE 2019

\begin{tabular}{|l|l|}
\hline Simon says, "Clap twice!" & They clap \\
\hline Clap three times! & (No respond) \\
\hline Sit down! & (No respond) \\
\hline Simon says, “Take your books!" & They take the books \\
\hline Pick up your pens! & (No respond) \\
\hline Simon says, "Write your name on the paper." & They write their name. \\
\hline
\end{tabular}

\section{Telephoning}

Materials : Telephone, phone numbers

Directions : Say the following - Ok class, listen carefully! Work in group. One group consists of ten students. I am going to play an audio recording, listen to a dialogue, write only some phone numbers mentioned.

Game Roles : The students (in a group) write some phone numbers in a dialogue. The first prize will be awarded to the group which writes the phone numbers completely.

3. Clock Faces

Materials : A clock or a watch

Directions : Say the following - Ok class, listen carefully! Work in group. One group consists of seven students. Look at your watch. Group A, your watch is 07:00, Group B, your watch is 08:15, Group C, and your watch is 09:30. Now let's play the game! Group B, your watch is 15 minutes late (Group B must write on the black board 08:00 (8 o'clock)), and so on.

Game Roles : the students (in a group) write some orders from the teacher about the time. The first prize will be awarded to the group which writes the time correctly.

\begin{tabular}{|l|l|l|}
\hline \multicolumn{1}{|c|}{ GROUP A (07:00) } & \multicolumn{1}{|c|}{ GROUP B (08:15) } & \multicolumn{1}{|c|}{ GROUP C (09:30) } \\
\hline You are late 30 minutes & You are fast 15 minutes & You are on time \\
\hline Quarter past seven & Half past eight & Five to nine \\
\hline Now is five to eight & Now is quarter to nine & Now is half past nine \\
\hline
\end{tabular}

\section{Marking Illustration}

Materials : Worksheets, pencil, crayon, and/or pen

Directions : pass out a sheet containing a set of pictures or symbols. Then give specific directions such as the following:

a. Cross out the sun with a blue crayon

b. Mark an "X" with a yellow crayon under the clown's right foot.

c. Make a purple star on the bottom of a specific object on the page.

Game Roles : The students (in a group) write some orders from the teacher about the drawing. The first prize will be awarded to the group which draws beautifully and correctly.

\section{Guess the Title of the Poem}

Materials : Poems, paper, and pencil (if the students compose their own poems)

Directions : Read poems such as the ones that follow; do not read the titles. After reading the poem, ask the students to guess the title. The students should be encouraged to write poems in their own language with a similar style and read them to the class, asking the class to guess the title.

Game Roles : The students write some poems from their own sentences. The first prize will be awarded to

\section{Name and Product} the students who are able to guess the title of the poem rightly and write the poems beautifully.

Materials : A plastic pack of instant noodle

Directions : Take a plastic pack of instant noodle or any other kinds. Read the cooking instruction such as the ones that follow; do not read the titles. After reading, ask the students to guess the name of the food mentioned. The students should be encouraged to write another cooking instruction from another kind of food with their own sentences and read them to the class, asking the class to guess the food name.

Game Roles : The students write some cooking instructions from their own sentences. The first prize will be awarded to the students who are able to guess the food's name rightly and write the cooking instruction correctly.

7. Listening to a Song

Materials : A simple English song

Directions : Play the song twice or three times, and let the students listen to the song seriously, and after that ask them to guess the title of the song.

Game Roles: The students listen to the song carefully. Afterwards, they fill the blanks to complete the song script. The winner is the one who is able to write the complete song perfectly and sing that 
VOL. 01 NO. 01, JUNE 2019

song beautifully.

\section{Conclusion}

1. Effective listening will produce successful listening. Effective means being able to understand the language (grammatical ability) and the way language is used in different situations (interactional ability). There are many kinds of effective listening mainly; communicative teaching listening, dictogloss, and listening game.

2. The reason of using listening in the classroom is to let the students to hear different varieties and accent of English instead of the voices of their teacher which may be full of idiosyncrasies.

3. The listening materials are geared with the students' needs, levels, and interests. Although they should be realistic, they may not always be absolutely authentic.

4. There six principles for listening; Encourage students to listen as often and as much as possible, help students prepare to listen, once may not be enough, encourage students to respond to the content of a listening, not just to the language, different listening stages demand different listening tasks, and good teachers exploitlistening texts to the full.

A. Suggestion

We suggest the English teachers to:

1. Improve their teaching style, their methods of teaching, and their technique of teaching English, especially teaching listening.

2. Overcome the difficulties of their students in listening using the communicative teaching of listening.

3. Apply the teaching listening in the classroom; in order to make their students is more confident than before.

\section{BIBBLIOGRAPHY}

Aziez, F., \& Alwasilah, A. C. (1996). Pengajaran Bahasa Komunikatif: Teori dan Praktek. PT Remaja Rosdakarya.

Barthes, R. (1985). The Responsibility of Forms: Critical Essays on Music, Art, and Representation, trans. Richard Howard (New York: Hill and Wang, 1985), 302.

Flood, J., Lapp, D., Squire, J. R., \& Jensen, J. M. (2003). Handbook of research on teaching the English language arts. ERIC.

Harmer, J. (2001). The practice of English language teaching. London/New York.

Harmer, J. (2008). How to teach English. ELT Journal, 62(3), 313-316.

Kernerman, L. (1996). Password: English Dictionary For Speakers Of Bahasa Indonesia. Jakarta: KesaintBalanc.

Rost, M. (2005). L2 Listening. In Handbook of research in second language teaching and learning (pp. 527552). Routledge. 